\title{
Chemical composition and nutritional quality of tilapia muscle tissue using the feed additive Enzimsporin
}

\author{
Tatiana Maslova*, Tatiana Kulakova \\ Vologda State Dairy Academy named after N.V. Vereshchagin, ul. Smidta 2, Vologda, 160555, Russia
}

\begin{abstract}
The production of ecologically clean fish products is in demand in the food market. As a result of the research, the nutritional quality and chemical composition of the muscle tissue of the Nile tilapia (Oreochromis niloticus L.) were evaluated using the pro-biotic additive Enzimsporin. A valuable quality of Nile tilapia meat is its high protein content. In the muscle tissue, the maximum amount of protein was $80.4 \%$, in the yearlings of the 1st experimental group, which is $7.51 \%(\mathrm{P} \geq 0.99)$ higher than in the control group. Yearlings of the 2 nd experimental group outperformed their peers from the control group by $4.8 \%$ $(\mathrm{P} \geq 0.95)$. Its amount in fry of Nile tilapia varied from $72.27-72.73 \%$ in the experimental groups to $74.71 \%$ in the control group. The fat content in fry varied from $9.55 \%$ in the control to $12.19 \%$ in the fish of the 2nd experimental group. The amount of lipids was the highest in the control variant of Nile tilapia yearlings (11.48\%), which is $6.48 \%$ more than in the 1 st experimental group and by $4.48 \%$ more than that in the 2 nd experimental group. The lipid-protein coefficient (0.06-0.09) of the experimental groups characterizes the meat as less tender, but high in protein, possessing lipotropic properties that protect the liver from fatty infiltration. The study of nutritional value and functional and technological properties shows that tilapia meat can be attributed to highly saturated food raw materials and used to obtain dietary products.
\end{abstract}

\section{Introduction}

Aquaculture is a rapidly developing branch of the region's fisheries. Artificial farming of fish in industrial conditions is the only promising alternative to fishing for providing the population with valuable and affordable fish products in conditions of a shortage of fish resources or deterioration of their quality in natural water bodies.

Currently, in the development of fish farming, much attention is paid to the intensive increase in commercial aquaculture production for the introduction of valuable fish species with high nutritional value, such as the Nile tilapia.

The cultivation of tilapia is of considerable interest and is explained by a number of biological characteristics and economically useful qualities that are inherent in these fish. They have broad adaptive capabilities, grow and reproduce well, are resistant to oxygen deficiency, increased organic content in water, and easily tolerate sharp temperature fluctuations. They reach the marketable mass in the first year of cultivation $[1,2]$.

Tilapia meat is distinguished by good taste, excellent nutritional properties, contains easily digestible proteins, vitamins and trace elements, and has a complete set of essential amino acids. As a fish product, tilapia has many health benefits. On the domestic market, it is sold fresh, chilled or frozen, as fish that is affordable and has a high nutritional and biological value.

\section{Materials and methods}

Under conditions of artificial cultivation, aquatic organisms are affected by a complex of stress factors which leads to a delay in development and an insufficient increase in fish production. These include a monotonous type of feeding, a high stocking density, which entails a deterioration in the hydrochemical parameters of water, and the likelihood of parasite contamination.

Recently, the use of compound feed in fish farming with the inclusion of spore-forming probiotic cultures and bacteria has become increasingly important, the use of which helps to maintain a healthy balance of the intestinal microflora of fish, strengthen immunity and improve the functional and technological properties of muscle tissue.

The scientists have developed a new feed probiotic Enzimsporin, which contains a complex of lyophilized spore-forming bacteria Bacillus subtilis and Bacillus licheniformis at a concentration of $5 \times 10^{9} \mathrm{CFU} / \mathrm{g}$, which determines a wide range of product action against pathogenic and opportunistic microorganisms (Registration number in Russia PVR 2-8.16/03297 as of September 26, 2016). Bacillus subtilis-hay stick. It is an antagonist of pathogenic and conditionally pathogenic microorganisms, such as Salmonella, proteus, staphylococci, streptococci, yeast fungi. It produces enzymes that remove the products of putrefactive 
decomposition of tissues. Restores the number of populations of lacto and bifidobacteria, Escherichia coli and other microorganisms that make up the normoflora of the gastrointestinal tract (GIT) and ensure its normal functioning. It synthesizes amino acids, vitamins and immunoactive substances.

Bacillus licheniformis. It produces a number of proteins, peptides, enzymes and vitamins, promotes the production of interferon, which destroy pathogenic microbes and viruses, leading to the normalization of the intestinal microflora. They promote the digestion of food, reduce food and chemical poisoning.

Bacillus subtilis natto. To improve the absorption of calcium and expand the spectrum of antagonistic activity of the target probiotic, the authors used a culture of Bacillus subtilis natto, which synthesizes various enzymes, vitamins, amino acids and other nutrients during fermentation.

Probiotic-designed to optimize the digestive processes, increase the productivity and safety of fish and other hydrobionts, has high thermal stability, which allows it to be introduced into feed during granulation and extrusion [3].

Effect of the action of probiotic cultures contained in "Enzimsporin", entering the digestive tract of hydrobionts:they stimulate the body's immune system, suppress the reproduction of pathogenic bacteria, and restore the balance of the symbiotic intestinal microflora. The digestibility of artificial fish feeds does not exceed $80 \%$. At the same time, a significant amount of undigested, rapidly decomposing pollutants enters the water from the metabolic processes. "Enzimsporin" promotes the activation of metabolic processes and increases the absorption of feed nutrients.

Probiotic is designed to optimize digestion processes, increase the productivity and safety of fish and other aquatic organisms, has a high thermal stability, which allows it to be introduced into feed during pelletizing and extrusion [3].

The aim of our research was to study the chemical composition and nutritional qualities of the muscle tissue of the Nile tilapia using the feed additive Enzimsporin.

\section{Results and discussion}

The studies were carried out on the basis of the Regional Center for Aquaculture Development of the Vologda Oblast. The object of the study was the Nile tilapia (Oreochromis niloticus L.) of different age groups. Individuals of each age group were similar in origin, age and body weight. The fish were grown in aquarium installations with the necessary equipment [4]. The study design is presented in Table 01 .

Table 1. Scheme of scientific and economic experiment

\begin{tabular}{|c|c|c|}
\hline Group & $\begin{array}{l}\text { Fish number } \\
\text { [pcs] }\end{array}$ & Feed conditions \\
\hline \multicolumn{3}{|r|}{ I experiment (fry) } \\
\hline Control & 50 & Basic ration BR (starting compound feed from Tetra) \\
\hline 1 Experimental & 50 & Basic ration $\mathrm{BR}+0.5 \mathrm{~g}$ probiotic $/ 1 \mathrm{~kg}$ of feed \\
\hline 2 Experimental & 50 & Basic ration $\mathrm{BR}+1 \mathrm{~g}$ probiotic/1 $\mathrm{kg}$ of feed \\
\hline \multicolumn{3}{|r|}{ II experiment (yearlings) } \\
\hline Control & 25 & Basic ration BR (extruded compound feed of Limkorm company) \\
\hline 1 Experimental & 25 & Basic ration $\mathrm{BR}+0.5 \mathrm{~g}$ probiotic/1 $\mathrm{kg}$ of feed \\
\hline 2 Experimental & 25 & Basic ration $\mathrm{BR}+1 \mathrm{~g}$ probiotic/1 $\mathrm{kg}$ of feed \\
\hline
\end{tabular}

The chemical composition of fish muscle tissue (moisture, protein and fat content) was carried out to the Federal State Budgetary Institution of Science "Vologda Scientific Center of the Russian Academy of Sciences" according to the GOST methods.

To characterize the nutritional value and functional and technological properties (FTP) of the muscle tissue of the studied fish, a number of coefficients were calculated analytically [5-11].

Food saturation coefficient (FSC) was calculated according to the following formula [6]:

$$
F S C=(P+F) / W,
$$

where FSC is food saturation coefficient, a.u.;

$\mathrm{P}$ is protein content, \%;

$\mathrm{F}$ is fat content, $\%$;

$\mathrm{W}$ is water content, $\%$.
The watering coefficient $(\mathrm{Cw})$ was calculated $[6,12]$ as the quantitative ratio of water and protein in muscle tissue by the following formula:

$$
\mathrm{Cw}=\mathrm{W} / \mathrm{P} \text {, }
$$

Where $\mathrm{Cw}$ is the waterin coefficient,

$\mathrm{P}$ is protein content, \%;

$\mathrm{W}$ is water content, $\%$.

The lipid-protein coefficient (Cf) of muscle tissue, which is an indicator of the tenderness of fish meat, was defined as the ratio of the fat content to the protein content and is determined by the following formula [13, 14]:

$$
\mathrm{Cf}=\mathrm{F} / \mathrm{P},
$$

where $\mathrm{Cf}$ is the lipid-protein coefficient;

$\mathrm{P}$ is protein content, \%;

$\mathrm{L}$ is lipid content, $\%$. 
The protein-water coefficient (PWC) shows the amount of protein (in grams) per $100 \mathrm{~g}$ of water $[5,6$, 13, 15]:

$$
\mathrm{PWC}=(\mathrm{P} / \mathrm{W}) \times 100,
$$

where $\mathrm{P}$ is protein content, \%;

$\mathrm{W}$ is water content, $\%$.

The protein-water-fat coefficient (PWFC) was calculated $[5,7,8,11,13]$ using the following formula:

$$
\mathrm{PWFC}=\mathrm{P} /(\mathrm{W}+\mathrm{F}),
$$

where $\mathrm{P}$ is protein content, \%;

$\mathrm{W}$ is water content, $\%$.

$\mathrm{F}$ is fat content, $\%$.
The experimental data obtained in the research were processed biometrically using the Microsoft Excel software package.

The chemical composition of tilapia varies depending on the age of the fish, the dietary spectrum and their physiological state[2, 12]. Studies of the qualitative body composition of tilapia have shown that the inclusion of experimental variants of the feed additive in the diet did not have a negative effect on the chemical composition of the muscle tissue of fish.

The muscle tissue of fish has a complex chemical composition. The content of the main components can vary quite significantly (Table 02 ).

Table 2. Biochemical parameters of fish muscle tissue (in \% of dry matter)

\begin{tabular}{|l|c|c|c|c|c|c|}
\hline \multirow{2}{*}{ Indicators } & \multicolumn{3}{|c}{ Nile tilapia fry } & \multicolumn{3}{c|}{ Nile tilapia yearlings } \\
\cline { 2 - 7 } & Control & 1 Experimental & 2 Experimental & Control & 1 Experimental & 2 Experimental \\
\hline Water, \% & $74.70 \pm 0.79$ & $74.32 \pm 1.02$ & $73.95 \pm 0.62$ & $73.46 \pm 0.14$ & $76.20 \pm 0.48$ & $77.92 \pm 2.09$ \\
\hline Lipids, \% & $9.55 \pm 2.07$ & $10.0 \pm 1.61$ & $12.19 \pm 1.03$ & $11.48 \pm 0.73$ & $5.0 \pm 0.24$ & $7.01 \pm 2.26$ \\
\hline Protein, \% & $74.71 \pm 2.06$ & $72.27 \pm 2.73$ & $72.73 \pm 1.79$ & $72.89 \pm 1.11$ & $80.4 \pm 1.08 * *$ & $77.69 \pm 1.23 *$ \\
\hline Ash, \% & - & - & - & $11.29 \pm 0.65$ & $12.9 \pm 0.28$ & $7.81 \pm 1.03$ \\
\hline Dry matter, \% & $24.33 \pm 0.80$ & $24.73 \pm 0.98$ & $24.90 \pm 0.51$ & $25.63 \pm 0.14$ & $22.96 \pm 0.47$ & $21.43 \pm 2.09$ \\
\hline
\end{tabular}

Note: $* \mathrm{P} \geq 0.95 ; * * \mathrm{P} \geq 0.99$ in relation to control

The body chemistry of tilapia has confirmed the high nutritional value of this fish species.

The different content of dry matter in the body of the control and experimental groups of yearlings is mainly caused by the uneven accumulation of lipids in the body. The process of lipid accumulation is directly related to the increase in body weight of fish. The fat content in fry varied from $9.55 \%$ in the control to $12.19 \%$ in the fish of the 2nd experimental group. The amount of lipids was the highest in the control variant of Nile tilapia yearlings $(11.48 \%)$, which is $6.48 \%$ more than in the 1 st experimental group and by $4.48 \%$, than that in the 2 nd experimental group. Therefore, according to this indicator, tilapia can be attributed to low-fat fish.

A valuable quality of Nile tilapia meat is its high protein content. In the muscle tissue, the maximum amount of protein was in the yearlings of the 1st experimental group $(80.4 \%)$, which is $7.51 \%(\mathrm{P} \geq 0.99)$ higher than in the control group. Yearlings of the 2nd experimental group outperformed their peers from the control group by $4.8 \%$ ( $\mathrm{P} \geq 0.95)$. Its amount in fry of
Nile tilapia varied from $72.27 \%-72.73 \%$ in the experimental groups to $74.71 \%$ in the control group.

No significant differences were found in the chemical composition of the body of juvenile tilapia grown using different dosages of feeding the probiotic preparation.

The nutritional value of fish is determined by the composition of the muscle tissue. According to the chemical composition data, it can be seen that more than half of the fish mass is water. It is water that determines the functional and technological properties, and also has a positive effect on the structure, consistency and yield of finished products as a result of technological processing $[12,15,16]$.

The values of the coefficients of the functional and technological properties of the muscle tissue of tilapia in terms of indicators are consistent with other coefficients: watering, protein-water and lipid-protein, protein-waterfat and the coefficient of food saturation are presented in Table 03 .

Table 3. Functional and technological properties of fish muscle tissue

\begin{tabular}{|c|c|c|c|c|c|c|}
\hline \multirow{2}{*}{ Indicators } & \multicolumn{3}{|c|}{ Nile tilapia fry } & \multicolumn{3}{c|}{ Nile tilapia yearlings } \\
\cline { 2 - 7 } & Control & 1 Experimental & 2 Experimental & Control & 1 Experimental & 2 Experimental \\
\hline FSC & 1.12 & 1.10 & 1.14 & 1.14 & 1.12 & 1.08 \\
\hline Cw & 0.99 & 1.02 & 1.01 & 1.0 & 0.94 & 1.0 \\
\hline PVC & 1.0 & 0.97 & 0.98 & 0.99 & 1.05 & 1.0 \\
\hline Cf & 0.12 & 0.13 & 0.16 & 0.15 & 0.06 & 0.09 \\
\hline PWFC & 1.12 & 1.16 & 1.18 & 1.16 & 1.0 & 1.09 \\
\hline
\end{tabular}


To characterize the biological value of the product, an assessment of the food saturation coefficient was made. The index of food raw materials can be subdivided into low-saturated (FSC $\leq 0.3$ ), mediumsaturated $(\mathrm{FSC}=0.3-0.6)$, and highly saturated $(\mathrm{FSC}>$ $0.6-1.5)[5,7,17]$

The data in Table 03 show that the FSC of tilapia muscle tissue is $1.08-1.14$, which indicates a low lipid content and a high protein and water content in the muscle tissue of aquatic organisms. According to this indicator, this type of fish can be attributed to highly saturated food raw materials and used to obtain dietary products.

The taste and texture of the finished product depends on the amount of water, proteins and lipids in fish meat [16]. The value of the ratio of the amount of protein in the muscle tissue of fish to the water content in it is called the protein-water coefficient (PWC) [5, 6, 12]. Based on the data of the chemical composition, the calculation method established that the protein-water coefficient was 0.98-1.05, which confirms the high protein content of the tilapia muscle tissue.

The protein-water-fat coefficient of the studied fish varied from 1.0 to 1.18 . Therefore, tilapia meat can be classified as high in protein, juicy and low in fat.

In our studies, the value of $\mathrm{Cw}(0.94-1.02)$ indicates the presence of water in the tissues and a significant decrease in lipid levels, which characterizes muscle tissue as dense and juicy.

Lipid-protein ratio shows the tenderness of fish meat. The higher the $\mathrm{Cw}$ index, the more tender structure the meat has $[7,15,14]$.

Based on the data obtained, the lipid-protein coefficient $(\mathrm{Cf})$ of muscle tissue in younger age groups does not differ much and is $0.12-0.16$. The value of the coefficient $\mathrm{Cf}$ of the muscle tissue of the yearlings of the control group corresponds to 0.15 , which is 2.5 times higher than that of the fish of the 1st experimental group and 1.6 times than that of the 2nd experimental group, which indicates a more delicate muscle tissue of the fish. The Cf index (0.06-0.09) of the experimental groups characterizes the meat as less tender, but high in protein, with lipotropic properties that protect the liver from fatty infiltration. Such meat and products from it are necessary for professional athletes and children, which contributes to their growth and development, as well as recovery after training $[9,18,19]$.

\section{Conclusion}

The results of the study of the functional and technological properties show that the meat of the Nile tilapia has a high nutritional value and good gastronomic quality [5, 12]. Analysis of the biochemical composition of fish muscle tissue indicates a high protein content and a low lipid content in yearlings of the experimental groups receiving the feed additive Enzimsporin [6, 13, 17]. The production of organic food products based on tilapia meat allows for an increase in the use of aquatic organisms as functional products.

\section{References}

1. V.A. Vlasov, A.V. Zhigin Bioresource production technology. (St. Petersburg, Lan, 2020).

2. O.I. Boronetskaya, Yu.A. Privezentsev Bulletin of TSKHA, 4,131-137, (2011).

3. V.V. Davakhia, E.V. Glagoleva, T.M. Voinova, M.I. Kartashov, A.I. Ovchinikov RU Patent No. 2675934 C2 Combined probiotic preparation based on spore-forming bacteria of the genus bacillus (variants) and the bacillus subtilis (natto) strain used as an additive to the preparation" (2018)

4. T.F. Maslova, P.V. Sesin, T.S. Kulakova Young researchers of agroindustrial and forestry complexes to regions. (pp. 236-240) Vologda. EC VGMHA. (2019)

5. M.V. Arnautov, V.V. Artemo, I.V. Burlachenko, V.V. Artemo, V.V. Gershunskaya, A.S. Safronov Proceedings of VNIRO. 171,170-179, (2018).

6. L.S. Baidalinova, A.S. Lysova, O. Ya. Mezenova Biotechnology of seafood: monograph. (Moscow, Mir, 2006)

7. L.S. Baidalinova, A.A.Yarzhombek Biochemistry of raw materials of water origin. (Moscow, MORKNIGA, 2011).

8. V.V. Baranov, I.V. Brazhnaya, V.A. Grokhovsky, A.M.Ershova Fish and fish products technology. (Moscow, Kolos, 2010).

9. S.P. Grigorenko, T.N. Exuzian Proceedings of universities. Food technology, 2-3, 126-127, (2004)

10. L. D. Petrova, V. D. Bogdanov (2019) Bulletin of the Kamchatka State Technical University. 42, 55-61.

11. T.M. Safronova, V.M. Datsun Raw materials and materials for the fishing industry. (Moscow, Mir, 2013)

12. V.D. Bogdanov, F.B.Volotka Bulletin of TINRO, 173, 280-292. (2013)

13. I.P. Levanidov Fish industry. 9, 50-51, 64-66. (1968).

14. I.V. Kizevetter, Biochemistry of raw materials of water origin: monograph. (Moscow, Food industry, 1973).

15. F.B. Volotka (2014) Substantiation of the technology of fish shaped products from coastal fish using brewer's grains. Retrieved from: http://diss.seluk.ru/di-prodovolstvieprodukty/693-1-obosnovanie-tehnologiiribnihformovannih-izdeliy-rib-pribrezhnogo-lovaispolzovaniem-pivnoy-drobini.php

16. V. D. Bogdanov Fish products with adjustable structure: monograph. (Moscow, Mir, 2005)

17. V.P. Tereshchenko Chemistry of food raw materials: monograph. (Kaliningrad, KSTU, 2004)

18. O.O. Borisova Nutrition for athletes: foreign experience and practical recommendations. (Moscow, Soviet sport, 2007) 
19. M.A. Kuznetsova, M.V. Savkina, T.A.

Tikhomirova Science-2020: Physical culture, sports, tourism: problems and prospects, 4 (29), 62-67 (2020) 